\title{
Metabolic effects of insulin and IGFs on gilthead sea bream (Sparus aurata) muscle cells
}

\section{Núria Montserrat ${ }^{\dagger \neq}$, Encarnación Capilla ${ }^{\ddagger}$, Isabel Navarro and Joaquim Gutiérrez *}

Departament de Fisiologia i Immunologia, Facultat de Biologia, Universitat de Barcelona, Barcelona, Spain

\section{Edited by:}

Gustavo M. Somoza, Instituto de Investigaciones

Biotecnologicas-Instituto Tecnologico

de Chascomus, Argentina

Reviewed by:

Elisabeth Eppler, University of Zürich, Switzerland

Mark Sheridan, North Dakota State

University, USA

*Correspondence:

Joaquim Gutiérrez, Departament de Fisiologia i Immunologia, Facultat de Biologia, Universitat de Barcelona, Avinguda Diagonal 643, 08028

Barcelona, Spain.

e-mail: jgutierrez@ub.edu

\section{${ }^{t}$ Present address:}

Núria Montserrat, Centre de

Medicina Regenerativa de Barcelona,

Dr. Aiguader, 88, 7th floor, 08003

Barcelona, Spain

${ }^{\ddagger}$ Núria Montserrat and Encarnación Capilla have contributed equally to this work.
Primary cultures of gilthead sea bream myocytes were performed in order to examine the relative metabolic function of insulin compared with IGF-I and IGF-II (insulin-like growth factors, IGFs) at different stages in the cell culture. In these cells, the in vitro effects of insulin and IGFs on 2-deoxyglucose (2-DG) and L-alanine uptake were studied in both myocytes (day 4) and small myotubes (day 9). 2-DG uptake in gilthead sea bream muscle cells was increased in the presence of insulin and IGFs in a time dependent manner and along with muscle cell differentiation. On the contrary, L-alanine uptake was also stimulated by insulin and IGFs but showed an inverse pattern, being the uptake higher in small myocytes than in large myotubes. The results of preincubation with inhibitors (PD-98059, wortmannin, and cytochalasin B) on 2-DG uptake indicated that insulin and IGFs stimulate glucose uptake through the same mechanisms, and evidenced that mitogenesis activator protein kinase (MAPK) and PI3K-Akt transduction pathways mediate the metabolic function of these peptides. In the same way, we observed that GLUT4 protein synthesis was stimulated in the presence of insulin and IGFs in gilthead sea bream muscle cells in a different manner at days 4 or 9 of the culture. In summary we describe here, for the first time, the effects of insulin and IGFs on 2-DG and L-alanine uptake in primary culture of gilthead sea bream muscle cells. We show that both MAPK and PI3K-Akt transduction pathways are needed in order to control insulin and IGFs actions in these cells. Moreover, changes in glucose uptake can be explained by the action of the GLUT4 transporter, which is stimulated in the presence of insulin and IGFs throughout the cell culture.

Keywords: insulin, insulin-like growth factors I and II, glucose and amino acid metabolism, muscle, sea bream, GLUT4

\section{INTRODUCTION}

The farming of gilthead sea bream, Sparus aurata, is one of the most important aquaculture industries in the Mediterranean area (FAO, 2009). In addition to the social and economic benefits that the development of aquaculture supposes worldwide, research to improve fish growth and development, especially in commercial species, is still missing. In order to do so, we believe that strategies that help us to understand the nutritional and endocrine regulation of fish growth are needed. On the other hand, taking into account that muscle in fish can account for more than $50 \%$ of the weight of an adult individual, and that muscle growth will determine the final size of the animal, the adoption of practices to manipulate fish growth are conditioned to the understanding of muscle growth regulating processes (reviewed by Johnston et al., 2011). Although recent advances have been made in terms of nutritional and environmental regulation of muscle formation, mostly in salmonids (Rescan et al., 1995; Johnston et al., 2011), data at the molecular and cellular level are scarce. The use of in vitro tools has recently allowed advancing in this matter. Therefore, in the present work we took advantage of using primary cultures of muscle satellite cells in order to study the role of insulin and the insulin-like growth factors (IGFs) in sea bream metabolism.
Cultures of muscle satellite cells as a model system to study muscle growth have been developed for different fish species (Fauconneau and Paboeuf, 2000; Castillo et al., 2002; Montserrat et al., 2007a), but in vitro, these satellite cells only differentiated to large myotubes for the studies undertaken on Oncorhynchus mykiss by some authors (Rescan et al., 1994, 1995; Fauconneau and Paboeuf, 1998). Our group described, for the first time, that the IGF system is implicated in both proliferation and differentiation processes, as well as in the regulation of the metabolic functions in cultured trout satellite muscle cells (Castillo et al., 2004; Codina et al., 2008) as reported previously in mammals (Beguinot et al., 1985; Ewton et al., 1994; Ciaraldi et al., 2001). The important role of the growth hormone (GH)/IGF-I axis coordinating postnatal skeletal muscle expansion and differentiation during early development has been clearly demonstrated both in fish (Reinecke et al., 2005) and in mammals (Florini et al., 1996). In mouse transgenic lines lacking IGF-I (and/or its receptor) embryonic development is impaired, resulting in a reduced growth in these animals (Florini et al., 1996). On the other hand, transgenic mice overexpressing GH have shown a dramatic two-fold growth enhancement (Ahrens and Devlin, 2011). Similarly, regarding fish, many species, and strains have been shown to be capable of being greatly growth stimulated either by using GH treatment or transgenesis, domestication, or selective 
breeding (Ahrens and Devlin, 2011). The accumulated evidence to date, suggests, that the major components of the IGF signaling system are also implicated in the growth of gilthead sea bream. During the past decades, in vivo studies on protein/energy ratio have shown the nutritional regulation of the IGF-I axis in gilthead sea bream (reviewed by Pérez-Sánchez and Le Bail, 1999). In the same scenario, other authors showed a positive correlation between IGF-I plasmatic values and changes in ration size in this species (Pérez-Sánchez et al., 1995; Marti-Palanca et al., 1996; Company et al., 1999). Lately, it has been demonstrated the role of GH and IGF-I on seasonal growth and the effect of diets with plant protein supply on nitrogen-metabolism and GH-liver axis (Mingarro et al., 2002; Gómez-Requeni et al., 2003, 2004). Importantly, our group recently described the role of insulin and IGF-I during the compensatory growth of the sea bream demonstrating their distinct actions in response to the nutritional status (Montserrat et al., 2007b).

Besides the growth actions of IGF-I, it has been demonstrated that both insulin and IGF-I play a critical role in the regulation of fish metabolism. Several studies in fish reported the action of insulin and IGF-I on glucose and amino acid uptake in distinct cell tissues (Inui and Ishioka, 1983; Negatu and Meier, 1995; Soengas and Moon, 1995, 1998; Gallardo et al., 2001; Navarro et al., 2003; Capilla et al., 2004; Castillo et al., 2004; Codina et al., 2008; Bouraoui et al., 2010). Moreover, Vega-Rubín de Celis et al. (2004) observed increases in glucose, glucagon, and insulin plasma levels when arginine was injected intraperitoneally on gilthead sea bream, demonstrating the interactions between amino acid metabolism and glucose homeostasis in this species. Interestingly, in our group, Rojas et al. (2004) partially cloned a specific glucose transporter (saGLUT4) from red muscle of gilthead sea bream, describing the effects of different experimental diets on its expression, and described that intraperitoneal administration of arginine on gilthead sea bream provoked increases in the levels of GLUT4 protein in white skeletal muscle.

Overall, all these data evidence the important role for insulin and IGFs in gilthead sea bream skeletal muscle physiology and homeostasis. However, we believe that all those findings remain to be analyzed in detail. In order to finally understand the role of the IGF system in muscle growth and development we used a primary culture of gilthead sea bream muscle cells previously described (Montserrat et al., 2007a). The aim of this study was to analyze the role of IGFs on metabolic processes such as glucose and amino acid uptake compared to insulin, and to identify the main signaling pathways undertaken by the IGF-I receptor by using specific inhibitors in gilthead sea bream muscle cells. Besides, we have detected stimulation of GLUT4 protein expression in those cells in the presence of the different peptides throughout the cell culture.

\section{MATERIALS AND METHODS CHEMICALS}

2-Deoxy-D-[2, 6- $\left.{ }^{3} \mathrm{H}\right]$ glucose with a specific activity of $43 \mathrm{Ci} / \mathrm{mmol}$ and $\mathrm{L}-\left[2,3-{ }^{3} \mathrm{H}\right]$ alanine with a specific activity of $52 \mathrm{Ci} / \mathrm{mmol}$ were purchased from Amersham Pharmacia Biotech Europe (Barcelona, Spain). Recombinant human IGF-I and IGF-II were purchased from Peninsula Laboratories Europe (Merseyside, UK). Anti-phospho-p44/42 (cat no 9106), anti-Akt (cat no 9272),
anti-Akt-P (cat no 9271), and anti-p44/42 (cat no 4696) antibodies were ordered from Cell Signaling Technology Inc. (Beberly, MA, USA). All the remaining reagents were purchased from SigmaAldrich Química S.A. (Madrid, Spain). The okGLUT4 (against GLUT4 from coho salmon, Oncorhynchus kisutch) antibody was a kind gift from Dr. Josep Planas (University of Barcelona) and has been previously well characterized (Capilla et al., 2004).

\section{ANIMALS AND CELL CULTURE}

We used gilthead sea breams (Sparus aurata) with weights ranging from 2.8 to $8.5 \mathrm{~g}$. Animals were provided by Aquamar S.L. (San Fernando, Cádiz, Spain). Fish were maintained in facilities at the Faculty of Biology (Barcelona) in closed-circuit flow systems at $19^{\circ} \mathrm{C}$, fed ad libitum with a commercial diet, and fasted for $24 \mathrm{~h}$ before the experiments. The fish (70-80 for each culture) were killed by a sharp blow to the head, weighted, and immersed in $70 \%$ ethanol for $30 \mathrm{~s}$ to sterilize external surfaces.

The procedure for the isolation of the satellite cells was performed following the protocol previously described for gilthead sea bream by Montserrat et al. (2007a). All experiments were conducted with cells seeded at a density of $2 \times 10^{6}$ cells per well in six-well plastic plates $\left(9.6 \mathrm{~cm}^{2} /\right.$ well, NUNC). Observations on morphology were regularly made to control the state of the cells, which were used at day 4/5 (myocytes and recently differentiated myotubes) and at day 9 (mostly small myotubes) for 2-deoxyglucose (2-DG) and L-alanine uptake assays and Western blotting. All experiments were performed three times; each condition was performed in triplicate (three wells). Cells were incubated at $21^{\circ} \mathrm{C}$, the optimal temperature for growth of the culture.

\section{L-ALANINE UPTAKE ASSAY}

For L-alanine uptake assays, after 4 or 9 days of culture, the medium (90\% Dulbecco's modified eagle medium $+10 \%$ fetal bovine serum, DMEM-FBS) was aspirated and the cells were rinsed with ice-cold phosphate buffer saline (PBS) and maintained in DMEM $+0.5 \%$ bovine serum albumin (DMEM-BSA) without FBS for 2-3 h. After preincubation with DMEM-BSA containing different concentrations of peptides (from 10 to $100 \mathrm{nM}$ for IGF-I or IGF-II and $100 \mathrm{nM}$ to $1 \mu \mathrm{M}$ for insulin) at different times ( 1 or $2 \mathrm{~h}$ ), the medium was aspirated, rinsed two times with ice-cold PBS, and the cells were incubated with $1 \mu \mathrm{Ci} / \mathrm{ml}$ of L-alanine for $20 \mathrm{~min}$. Previously, time course experiments were performed to find the best conditions for the study (data not shown). The amino acid uptake was stopped by aspiration of the supernatant, followed by three rapid washes with ice-cold PBS. Next, cells were solubilized with $\mathrm{NaOH} 0.1 \mathrm{~N}$. Finally, the samples were placed in scintillation vials, and the radioactivity was counted with a TRICARB $2100 \beta$-counter (Packard Bioscience, Meriden, CT, USA).

\section{2-DG UPTAKE ASSAYS}

For 2-DG assays, the cells after 4 or 9 days of culture, were incubated for $4 \mathrm{~h}$ with DMEM-BSA without FBS and after this period pre-incubated ( 30 or $60 \mathrm{~min}$ ) in the presence or absence of insulin $(1 \mu \mathrm{M})$, IGF-I $(100 \mathrm{nM})$, or IGF-II $(100 \mathrm{nM})$ in DMEM-BSA. After preincubation, the cells were rinsed two times with icecold PBS and incubated with unlabeled $50 \mu \mathrm{M}$ 2-DG together 
with labeled 2-DG $(2 \mu \mathrm{Ci} / \mathrm{ml})$ in HEPES-saline buffer. The incubations with labeled and cold 2-DG, except for the time course experiments, were routinely of $30 \mathrm{~min}$. The contents of the wells were aspirated and rinsed three times with ice-cold PBS, and the cells were lysed with $\mathrm{NaOH} 0.5 \mathrm{~N}$. The contents of the wells were removed and placed into scintillation vials, and the radioactivity was quantified with a TRICARB $2100 \beta$-counter (Packard Bioscience, Meriden, CT, USA).

In order to better characterize glucose transport the effects of several compounds on glucose uptake stimulation by insulin and IGFs were analyzed at day 5 in the cell culture. PD-98059 is an inhibitor of the MEK1 protein, a component of the mitogenesis activator protein kinase (MAPK) pathway; wortmannin is an inhibitor of the PI3K-Akt pathway; and cytochalasin B is a specific inhibitor of the facilitative glucose transporters. Cells were pre-incubated for $30 \mathrm{~min}$ with wortmannin $(1 \mu \mathrm{M})$ or PD-98059 $(50 \mu \mathrm{M})$, and peptides (IGF-I, IGF-II, or insulin) were added for 30 additional min. The cytochalasin B $(20 \mu \mathrm{M})$ was added and incubated simultaneously with the labeled 2-DG for $30 \mathrm{~min}$. Doses of inhibitors were selected from previous results obtained in similar experiments by Castillo et al. (2004).

\section{WESTERN BLOT ANALYSIS}

In order to characterize the signal transduction pathways, following 4 days in culture, the cells were incubated with DMEM-BSA for 2-3 h. Next, cells were pre-incubated for $30 \mathrm{~min}$ with wortmannin $(1 \mu \mathrm{M})$ or PD-98059 $(50 \mu \mathrm{M})$. Afterward, cells were stimulated in the presence of a fixed concentration of peptides ( $100 \mathrm{nM}$ for IGF-I and IGF-II or $1 \mu \mathrm{M}$ for insulin) for $30 \mathrm{~min}$ with DMEM-BSA. Subsequently, the medium was aspirated, the wells were washed with ice-cold PBS, and the cells were lysed with lysis buffer (1\% NP-40, $0.4 \mathrm{mM}$ sodium orthovanadate, $10 \mathrm{mM}$ Tris, $140 \mathrm{mM} \mathrm{NaCl}, 5 \mathrm{mM}$ EDTA, $50 \mathrm{mM} \mathrm{NaF}, 1 \mathrm{mM}$ PMSF, $10 \mu \mathrm{g} / \mathrm{ml}$ Aprotinin, $10 \mu \mathrm{g} / \mathrm{ml}$ Leupeptin, $\mathrm{pH}$ 7.6). After obtaining the cell lysates, protein content was determined with the Bradford reagent method (Bradford, 1976) and electrophoresis using a polyacrylamide gel was conducted in the presence of SDS (SDS-PAGE; each lane loaded with $30 \mu \mathrm{g}$ of protein). Samples were then transferred to a PVDF membrane for 90 min under a constant current of $1 \mathrm{~A}$ in a transfer buffer (25 mM Tris-HCl, $190 \mathrm{mM}$ Glycine, 20\% Methanol, pH 7.5). Following a $30 \mathrm{~min}$ wash $(10 \mathrm{mM}$ Tris- $\mathrm{HCl}, 100 \mathrm{mM} \mathrm{NaCl}$, $0.1 \%$ Tween $20, \mathrm{pH} 7.5$ ) the membrane was incubated for $1 \mathrm{~h}$ at room temperature with the primary antibody (at 1:500 dilution). The primary antibodies detected the presence of MAPK and its active form (MAPK-P), as well as the Akt protein and its phosphorylated form (Akt-P).

Lysates of cells at day 4 and day 9, stimulated with $100 \mathrm{nM}$ IGF-I or IGF-II or $1 \mu \mathrm{M}$ insulin for $1 \mathrm{~h}$ were performed for the detection of GLUT4. Immunoblots were performed using the okGLUT4 antibody at 1:500 dilution in Tris-buffered saline containing $0.1 \%$ Tween 20 and $5 \%$ non-fat dry milk for $2 \mathrm{~h}$ at room temperature. The secondary antibody was used at 1:5000 dilution in the same buffer, and the detection of the luminescence was done using an enhanced chemiluminescence kit (Amersham, Barcelona, Spain). After developing with an automated film processor, the $\mathrm{x}$ ray films from three independent experiments were scanned and the intensity of the bands evaluated using the software TotalLab.

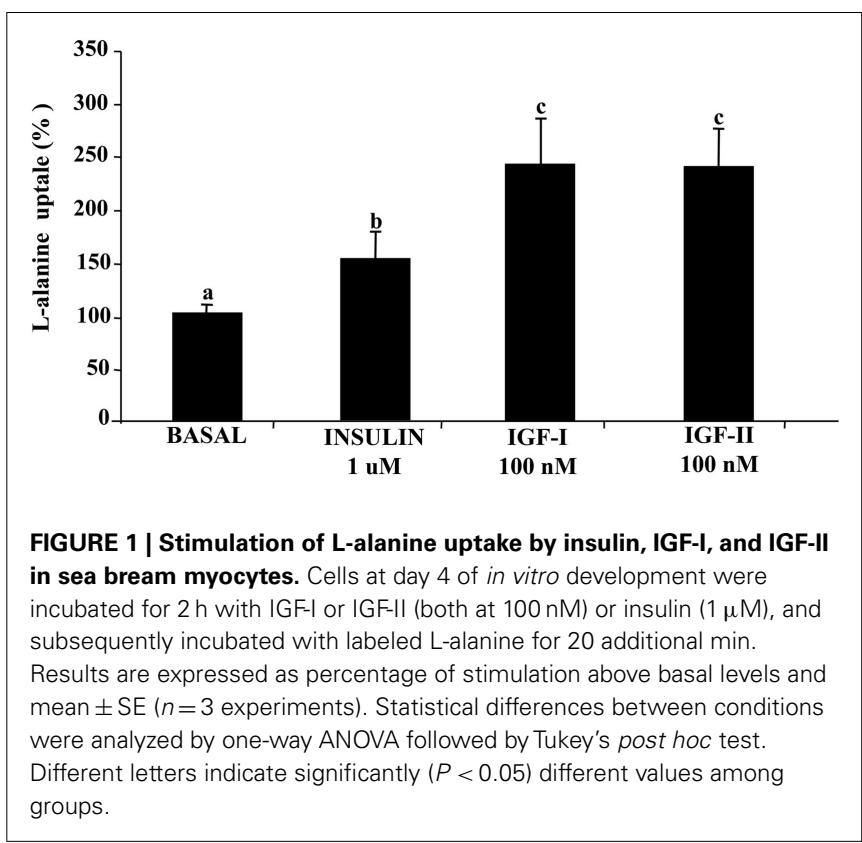

\section{STATISTICAL ANALYSIS}

The different treatments were performed in triplicate for each experiment. Data are presented as means \pm SE of at least three independent experiments. Statistical differences between conditions in Figures 1, 2 and 4 were analyzed by one-way analysis of variance (ANOVA) followed by the Tukey's post hoc test; and by two-ways ANOVA for the data presented in Table 1 regarding the signaling pathways activities. In Figure 3 statistical differences between inhibitors treatments within each hormonal condition were analyzed by one-way ANOVA followed by Tukey's post hoc test; and also, statistical differences between hormonal treatments in basal conditions were analyzed by another one-way ANOVA and the Tukey's post hoc test. In all cases, differences were considered statistically significant at $P<0.05$.

\section{RESULTS}

\section{IGF-I, IGF-II, AND INSULIN EFFECTS ON L-ALANINE UPTAKE}

The effects of IGF-I, IGF-II, and insulin on alanine uptake were analyzed at day 4 in the cell culture. As shown in Figure 1, all the tested peptides significantly stimulated alanine uptake over the basal values. IGF-I and IGF-II showed higher stimulation of alanine uptake when compared to insulin, also considering that IGF-I and IGF-II concentration was 10 times lower than that of insulin.

When the same experiment was carried out in cells at day 9 of the culture (myotubes), the same tendency was observed, but both, the basal and stimulated alanine uptake levels were clearly lower than those found in myocytes at 4 days of culture (data not shown).

\section{IGF-I, IGF-II, AND INSULIN EFFECTS ON 2-DG UPTAKE}

Figure 2A shows the effects of IGF-I and IGF-II compared with insulin on glucose uptake on muscle cells at day 4 . The preincubation of the cells with the peptides extended for 30 or $60 \mathrm{~min}$, and glucose uptake was fixed at $30 \mathrm{~min}$. In general, preincubating 


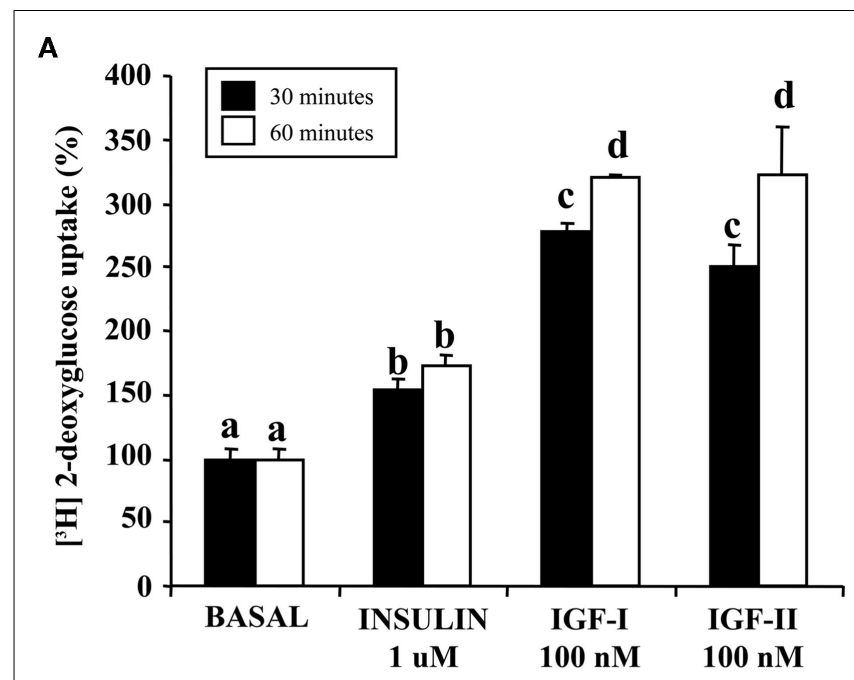

B

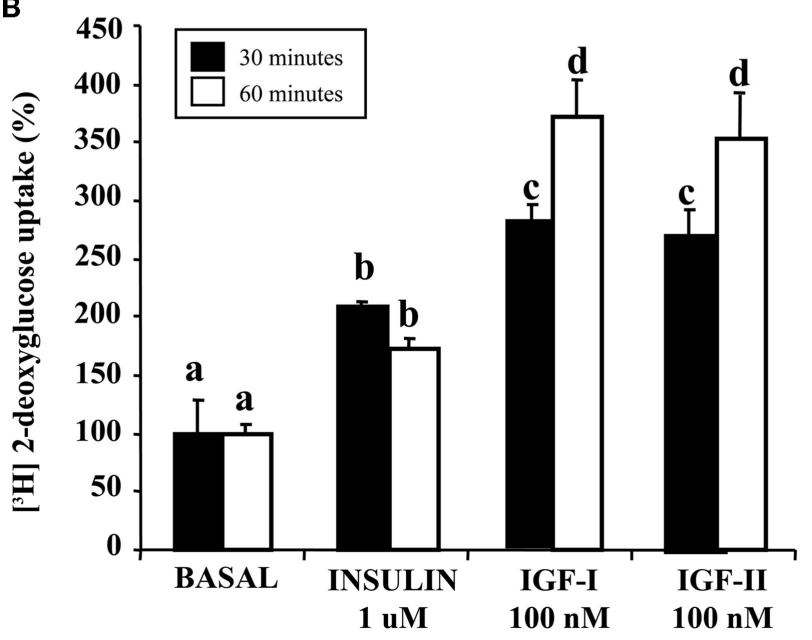

FIGURE 2 | Effect of insulin, IGF-I, and IGF-II on 2-deoxyglucose uptake in sea bream muscle cells. Cells were isolated and cultured for 4 days to have myocytes (A) or 9 days to obtain small myotubes (B) and incubated with the peptides, IGF-I or IGF-II (both at $100 \mathrm{nM}$ ) or insulin $(1 \mu \mathrm{M})$ for 30 or $60 \mathrm{~min}$, and subsequently incubated with labeled 2-deoxyglucose (2-DG) for 30 additional min. Results are expressed as percentage of stimulation above basal levels and means \pm SE ( $n=3$ experiments). Statistical differences between conditions were analyzed by one-way ANOVA followed by Tukey's post hoc test. Different letters indicate significantly $(P<0.05)$ different values among groups.

the cells during $60 \mathrm{~min}$ in the presence of the different peptides resulted in higher stimulatory effects on glucose uptake. IGF-I and IGF-II showed higher stimulation of glucose uptake when comparing to insulin effects.

As shown in Figure 2B, the same experiments were performed at day 9 of the cell culture, and the stimulatory effects of both IGF-I and IGF-II were again higher than those exerted by insulin after either 30 or $60 \mathrm{~min}$ of incubation.

The effects of the different inhibitors on glucose uptake stimulated by IGF-I, IGF-II, and insulin on day 5 myocytes are shown

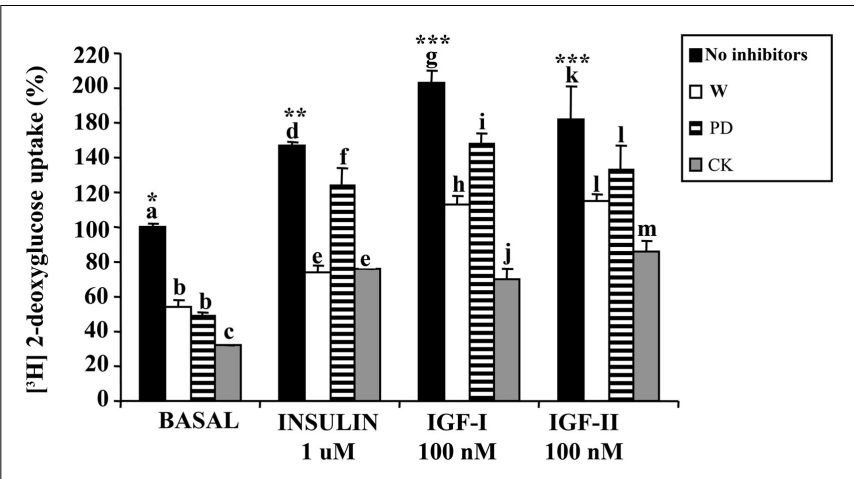

FIGURE 3 | Effect of inhibitors on 2-deoxyglucose uptake in sea bream myocytes. Cells at day 5 were pre-incubated for 30 min with wortmannin (W, $1 \mu \mathrm{M}$ ) or PD-98059 (PD, $50 \mu \mathrm{M}$ ). Next, IGF-I or IGF-II (both at $100 \mathrm{nM}$ ) or insulin $(1 \mu \mathrm{M})$ were added for 30 additional min. Cytochalasin $B(C K, 20 \mu \mathrm{M})$ was incubated for $30 \mathrm{~min}$. Results are expressed as percentage of stimulation over basal levels and mean \pm SE ( $n=3$ experiments). Statistical differences between inhibitors treatments within each hormonal condition were analyzed by one-way ANOVA followed by Tukey's post hoc test. Different letters indicate significantly $(P<0.05)$ different values among inhibitors treatments (different letters have been used for each hormonal group). Also, statistical differences between hormonal treatments in basal conditions were analyzed by one-way ANOVA followed by Tukey's post hoc test and are indicated with a different number of asterisks when $P<0.05$.

in Figure 3. Both PD-98059 and in a higher degree wortmannin, significantly inhibited the basal glucose uptake and the stimulatory effects of IGF-I, IGF-II, and insulin. The same results were found when the cells were incubated in the presence of the glucose transporter inhibitor, cytochalasin B.

\section{INHIBITION OF Akt AND MAPK SIGNALING PATHWAYS}

The effects of the specific inhibitors from both signaling pathways on day 4 cells are shown in Table 1. Preincubation of the cells with wortmannin (inhibitor of the Akt signaling pathway) reduced the IGF-I and IGF-II stimulated phosphorylation of Akt protein (from 237 to $67 \%$ and 345 to $56 \%$ above basal values, respectively). The effect of PD-98059 (inhibitor of the MAPK signaling pathway) reduced the effects of both IGF-I and IGF-II on MAPK phosphorylation (from 146 to $34 \%$ and 231 to $45 \%$, respectively). Neither of the inhibitors had any crossed effect on the other pathway.

\section{IMMUNODETECTION OF GLUT4}

With the use of an anti-okGLUT4 polyclonal antibody, a band of approximately $50 \mathrm{kDa}$ was detected at day 4 and day 9 sea bream muscle cells (Figure 4). Specificity of the $50-\mathrm{kDa}$ band was confirmed by the use of preimmune serum (data not shown). At day 4 the incubation of myocytes with $1 \mu \mathrm{M}$ insulin for $30 \mathrm{~min}$ resulted in GLUT4 stimulation (50\% above basal levels), whereas no changes of GLUT4 protein expression were observed when these cells were incubated neither with IGF-I nor IGF-II (100 nM). When myotubes of day 9 were incubated with $100 \mathrm{nM}$ IGF-I or IGF-II for $30 \mathrm{~min}$, GLUT4 protein expression was increased $\sim 200 \%$ above basal levels. The incubation with $1 \mu \mathrm{M}$ insulin did not cause a significant stimulatory effect on GLUT4 protein levels at this time as that caused by the IGFs. 


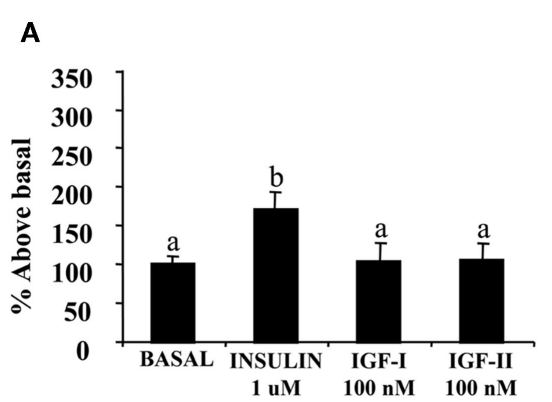

FIGURE 4 | GLUT4 levels in gilthead sea bream muscle cells during development. (A) Myocytes (day 4) and (B) small myotubes (day 9) were incubated with insulin (1 $\mu \mathrm{M})$, IGF-I, or IGF-II (both at $100 \mathrm{nM}$ ) for $60 \mathrm{~min}$ and subsequently lysed. Thirty micro gram of protein were loaded in each lane and subjected to $10 \%$ SDS-PAGE under reducing conditions. Western blot was performed with a primary antibody

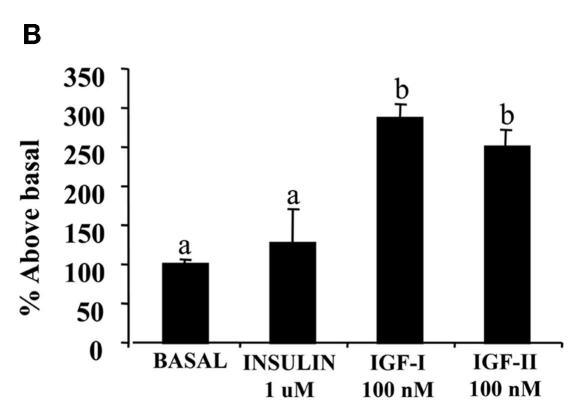

against GLUT4 (final dilution 1:500) and a secondary antibody anti-rabbit (1:5000). Results are expressed as percentage of band intensity above basal and mean \pm SE ( $n=3$ experiments). Statistical differences between conditions were analyzed by one-way ANOVA followed by Tukey's post hoc test. Different letters indicate significantly $(P<0.05)$ different values among groups.

Table 1 | Effect of inhibitors on the MAPK and PI3K-Akt pathways in IGF-I or IGF-II treated sea bream myocytes.

\begin{tabular}{|c|c|c|c|c|c|c|c|}
\hline & No treatment $(\%)$ & IGF-I 100 nM (\%) & $\begin{array}{l}\text { IGF-I } 100 \mathrm{nM}+ \\
\mathrm{W}(1 \mu \mathrm{M} ; \%)\end{array}$ & $\begin{array}{l}\text { IGF-I } 100 \mathrm{nM}+ \\
\text { PD (50 } \mu \mathrm{M} ; \%)\end{array}$ & IGF-II 100 nM (\%) & $\begin{array}{l}\text { IGF-II } 100 \mathrm{nM}+ \\
\mathrm{W}(1 \mu \mathrm{M} ; \%)\end{array}$ & $\begin{array}{l}\text { IGF-II } 100 \mathrm{nM}+ \\
\text { PD (50 } \mu \mathrm{M} ; \%)\end{array}$ \\
\hline MAPK-P & $100^{a}$ & $146 \pm 23^{b}$ & $123 \pm 29^{c}$ & $34 \pm 4^{d}$ & $231 \pm 19^{e}$ & $187 \pm 17^{f}$ & $45 \pm 19^{d}$ \\
\hline Akt-P & $100^{a}$ & $237 \pm 17^{b}$ & $67 \pm 17^{c}$ & $212 \pm 17^{d}$ & $345 \pm 17^{e}$ & $56 \pm 9^{c}$ & $314 \pm 19^{f}$ \\
\hline
\end{tabular}

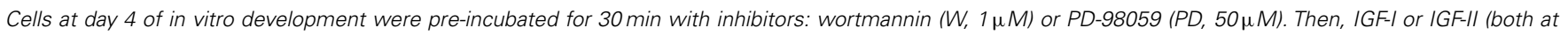

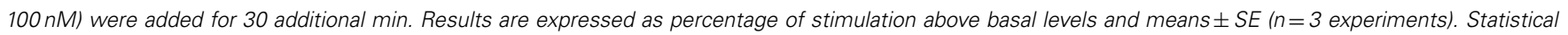

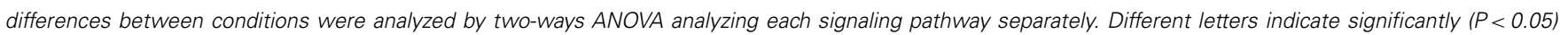
different values among groups.

\section{DISCUSSION}

This study is the first report on the metabolic effects of insulin and IGFs on cultured gilthead sea bream myocytes. Although the implication of insulin and IGF-I in growth processes have been reported in this species in vivo, the lack of information regarding the role of these peptides on sea bream muscle metabolism led us to examine the insulin and IGFs-stimulated uptake of metabolic substrates (2-DG and L-alanine). The use of specific inhibitors of the main signaling pathways confirmed that MAPK and PI3KAkt pathways are implicated in glucose metabolism in gilthead sea bream cultured muscle cells. On the other hand, the inhibitory effect of cytochalasin B on insulin and IGFs 2-DG stimulation, together with the detection of a GLUT4 transporter in sea bream myocytes, reveals the role of the studied peptides on sea bream glucose metabolism.

Muscle growth dynamics in fish results in large part from stimulation of protein synthesis, which directly depends on amino acids availability (Brodeur et al., 2003). Our data clearly showed that both IGF-I and IGF-II are more effective than insulin in stimulating L-alanine uptake at day 4 myocytes. Previous work has demonstrated the stimulatory effects on amino acid uptake of insulin and IGF-I, respectively, in fish muscle (Inui and Ishioka, 1983; Negatu and Meier, 1995). More recently, higher stimulatory effects for IGF-I than for insulin have been demonstrated in trout isolated cardiomyocytes (Gallardo et al., 2001) and on cultured rainbow trout myocytes (Castillo et al., 2004). However, the stimulatory effect of the peptides on L-alanine uptake in our study, is more effective in early stages of the cell culture (day 4) than at day 9. These data support the idea that amino acid requirement seems to be more important during proliferative stages than during cell muscle development (Castillo et al., 2004).

Fish are generally thought to have a limited ability to utilize carbohydrate when compared to mammals (Legate et al., 2001). The skeletal muscle is the main tissue responsible for eliminating plasma glucose in brown trout after a glucose load (Blasco et al., 1996). In the current study we investigated the role of IGF-I and IGF-II compared with insulin, in the 2-DG uptake in sea bream myocytes.

The present data showed that IGFs are more effective than insulin in stimulating glucose uptake in both myocytes and large myotubes; however, the stimulation increased along muscle cells differentiation in vitro. Previous studies in cultured rainbow trout myocytes showed similar results (Castillo et al., 2004), but no data was available to date in gilthead sea bream muscle cells. Recently, Navarro et al. (2003) and Bouraoui et al. (2010) demonstrated also that IGF-I had higher stimulatory effects than insulin in 2DG uptake in isolated sea bream adipocytes and primary culture of trout adipocytes, respectively. In the same way, previous work in mammals showed that IGF-I and IGF-II stimulated 2-DG uptake in rat and human muscle cells (Beguinot et al., 1985; Bevan et al., 1992; Zierath et al., 1992). Although the type II IGF-receptor has been identified in brown trout by our group (Méndez et al., 2001), studies in mammalian cells based on ligand competition (Ewton et al., 1987), IGF-II analogs (Burguera et al., 1994), and the use of 
an antibody to the type II IGF-receptor (Kiess et al., 1987), have suggested that the biological effects of both IGFs are mediated by the type I IGF-receptor.

Results in this study, have demonstrated that both IGF-I and IGF-II had higher stimulatory effects on 2-DG glucose uptake than those described by Castillo et al. (2004) and Codina et al. (2008) in rainbow trout myocytes at similar concentrations of peptides. Increases in absolute 2-DG uptake stimulation by IGFs throughout the cell culture might be related to the reported increase in IGF-I receptor levels, as well as to the higher metabolic needs in differentiated myotubes than in myocytes (Montserrat et al., 2007a).

In order to determine the specificity underlying the glucose uptake process, we incubated day 5 sea bream myocytes in the presence of PD-98059 and wortmannin. In agreement with the observations of Castillo et al. (2004) in rainbow trout myocytes, we found out a decrease on insulin and IGFs 2-DG stimulation, which indicates that both, MAPK and PI3K-Akt pathways are implicated in glucose metabolism in fish muscle. In addition, the use of cytochalasin B blocked the stimulatory effects of insulin and IGFs, suggesting that glucose transport takes place thought specific facilitative transporters in sea bream cultured myocytes. Previous studies on fish reported the existence of cytochalasin B-sensitive glucose transport in red blood cells of the eel (Tse and Young, 1990; Soengas and Moon, 1995) the primitive hagfish (Young et al., 1994) and in the black bullhead (Soengas and Moon, 1998). More recently, 2-DG uptake was inhibited by cytochalasin B in Xenopus laevis oocytes expressing an insulin-responsive glucose transporter (GLUT4) cloned from salmon (okGLUT4; Capilla et al., 2004). These previous findings led us to check the presence of the specific GLUT4 transporter in sea bream myocytes. In the present study, GLUT4 protein synthesis was stimulated by IGFs and insulin in a different manner throughout the cell culture. In mammals, several studies reported the stimulation of IGF-II in GLUT4 protein synthesis (Kaliman et al., 1996), as well as the effects of insulin on GLUT4 transcription in human muscle cell cultures (Al-Khalili et al., 2003). Similarly, an insulin injection in vivo was shown to induce an increase in GLUT4 mRNA expression and protein content in trout muscle (Capilla et al., 2002; Diaz et al., 2007). Current efforts in our laboratory are underway to examine whether insulin and IGFs stimulate the protein synthesis of GLUT4 in gilthead sea bream muscle cells.

On the other hand, it has been widely described in mammals that acute insulin treatment stimulates glucose transport in adipocytes and myocytes, largely by mediating translocation of GLUT4 from an intracellular compartment to the plasma membrane, as reviewed by Pessin and Saltiel (2000). In the same way, the effects of IGF-I in 2-DG uptake on L6 cells overexpressing the GLUT4 transporter where higher than in wild type L6 cells

\section{REFERENCES}

Ahrens, R. N. M., and Devlin, R. H. (2011). Standing genetic variation and compensatory evolution in transgenic organisms: a growthenhanced salmon simulation. Transgenic Res. 20, 583-597.
Al-Khalili, L., Chibalin, A. V., Kannisto, K., Zhang, B. B., Permert, J., Holman, G. D., Ehrenborg, E., Ding, V. D., Zierath, J. R., and Krook, A. (2003). Insulin action in cultured human skeletal muscle cells during differentiation: assessment of cell surface

(Lawrence et al., 1992). More recently, also in L6 muscle cells, the stimulatory effects of a glutamate receptor agonist (homocysteine sulfinic acid) on 2-DG uptake and GLUT4 translocation have been reported (Kim et al., 2011).

Previous findings in our group showed the stimulatory effects of insulin and IGFs on Akt phosphorylation in cultured sea bream myocytes (Montserrat et al., 2007a). The present work suggested that such an increase in Akt phosphorylation throughout the cell culture could be related to the observed increase of GLUT4 protein content after insulin and IGFs incubations, and this observation is also supported by the inhibitors (wortmannin and cytochalasin B) results. In fact, studies in a number of cell types including myocyte, myotubes, and adipocytes, related GLUT4 translocation to the plasma membrane with PI3K promotion of Akt phosphorylation (Wilson et al., 1995; Zorzano et al., 2000; Saltiel and Kahn, 2001; Rauch and Loughna, 2005). In the same way, it has been shown that expression of either constitutively active PI3K (Tengholm and Meyer, 2002) or Akt (Kohn et al., 1996) is sufficient to stimulate GLUT4 translocation and insertion to the plasma membrane to an extent comparable to that observed with insulin alone. Thus, the increase in the insulin-IGFs-stimulated increment in 2DG uptake in sea bream myocytes, may be in part explained by either enhanced insulin-IGFs-stimulated GLUT4 protein synthesis, or translocation of the transporter to the membrane through the PI3K-Akt phosphorylation reported in this study.

In conclusion, stimulatory effects of both, IGF-I and IGF-II on L-alanine uptake were higher than those found by insulin in day 4 sea bream muscle cells, and this stimulatory effect decreased with cell differentiation. In the same way, again both IGFs exerted higher stimulatory effects than insulin in 2-DG uptake, being more remarkable at day 9 myotubes. The stimulatory effects from both IGF-I and IGF-II in 2-DG uptake in differentiated myotubes, together with the stimulation of GLUT4 protein content, reveals the important role of those peptides in fish glucose metabolism. Interestingly, these findings showed for the first time in this species the metabolic role of IGF-II in sea bream muscle cells. Thus, our in vitro sea bream myocyte cells culture system offers a suitable model to further analyze the link between nutritional status and skeletal muscle function in fish.

\section{ACKNOWLEDGMENTS}

We thank Dr. Mancera from the University of Cádiz (Spain) for providing the gilthead sea breams, Dr. P. Castelló from the (Departament de Vertebrats, Universitat de Barcelona) for the maintenance of the fish and Dr. J. Planas (Departament de Fisiologia, Universitat de Barcelona) for the GLUT4 antibody. This work has been supported by funds from the "Ministerio de Ciencia e Innovación, MICINN" (AGL2008-00783, AGL2009-12427, AGL2010-17324 and AGL2011-24961) and XRAQ (Generalitat de Catalunya).

GLUT4 and GLUT1 content. Cell. Mol. Life Sci. 60, 991-998.

Beguinot, F., Kahn, C. R., Moses, A. C., and Smith, R. J. (1985). Distinct biologically active receptors for insulin, insulin-like growth factor I, and insulin-like growth factor-II in cultured skeletal muscle cells. J. Biol. Chem. 260, 15892-15898.

Bevan, S. J., Parry-Billings, M., Opara, E., Liu, C. T., Dunger, D. B., and Newsholme, E. A. (1992). The effect of insulin-like growth factor II on glucose uptake and metabolism in 
rat skeletal muscle in vitro. Biochem. J. 286, 561-565.

Blasco, J., Fernandez-Borras, J., Marimon, I., and Requena, A. (1996). Plasma glucose kinetics and tissue uptake in brown trout in vivo: effect of an intravascular glucose load. J. Comp. Physiol. B Biochem. Syst. Environ. Physiol. 165, 534-541.

Bouraoui, L., Capilla, E., Gutiérrez, J., and Navarro, I. (2010). Insulin and insulin-like growth factor I signaling pathways in rainbow trout (Oncorhynchus mykiss) during adipogenesis and their implication in glucose uptake. Am. J. Physiol. Regul. Integr. Comp. Physiol. 299, R33-R41.

Bradford, M. M. (1976). A rapid and sensitive method for quantitation of microgram quantities of protein utilizing the principle of protein-dye binding. Anal. Biochem. 72, 248-252.

Brodeur, J. C., Calvo, L., and Johnston, I. A. (2003). Proliferation of myogenic progenitor cells following feeding in the sub-Antarctic notothenioid fish Harpagifer bispinis. J. Exp. Biol. 206, 163-169.

Burguera, B., Elton, C. W., Caro, J. F., Tapscott, E. B., Pories, W. J., Dimarchi, R., Sakano, K., and Dohm, G. L. (1994). Stimulation of glucose uptake by insulin-like growth factor II in human muscle is not mediated by the insulin-like growth factor II/mannose 6-phosphate receptor. Biochem. J. 300, 781-785.

Capilla, E., Díaz, M., Albalat, A., Navarro, I., Pessin, E., Keller, K., and Planas, J. V. (2004). Functional characterization of an insulin-responsive glucose transporter (GLUT4) from fish adipose tissue. Am. J. Physiol. Endocrinol. Metab. 287, E348-E357.

Capilla, E., Diaz, M., Gutierrez, J., and Planas, J. V. (2002). Physiological regulation of the expression of a GLUT4 homolog in fish skeletal muscle. Am. J. Physiol. Endocrinol. Metab. 283, E44-E49.

Castillo, J., Codina, M., Martinez, M. L., Navarro, I., and Gutierrez, J. (2004). Metabolic and mitogenic effects of IGF- I and insulin on muscle cells of rainbow trout. Am. J. Physiol. Regul. Integr. Comp. Physiol. 286, R935-R941.

Castillo, J., Le Bail, P. Y., Paboeuf, G., Navarro, I., Weil, C., Fauconneau, B., and Gutierrez, J. (2002). IGF-I binding in primary culture of muscle cells of rainbow trout: changes during in vitro development. Am. J. Physiol. Regul. Integr. Comp. Physiol. 283, R647-R652.

Ciaraldi, T. P., Carter, L., Seipke, G., Mudaliar, S., and Henry, R. R. (2001). Effects of the long-acting insulin analog insulin glargine on cultured human skeletal muscle cells: comparison to insulin and IGFI. J. Clin. Endocrinol. Metab. 86, 5838-5847.

Codina, M., Garcia de la serrana, D., Sanchez-Gurmaches, J., Montserrat, N., Chistiakova, O., Navarro, I., and Gutierrez, J. (2008). Metabolic and mitogenic effects of IGF-II in rainbow trout (Oncorhynchus mykiss) myocytes in culture and the role of IGF-II in the PI3K/Akt and MAPK 4 signalling pathways. Gen. Comp. Endocrinol. 157, 116-126.

Company, R., Calduch-Giner, J. A., Pérez-Sánchez, J., and Kaushik, S. J. (1999). Protein sparing effect of dieatary lipids in common dentex (Dentex dentex): a comparative study with sea bream (Sparus aurata) and seabass (Dicentrarchus labrax). Aquat. Living Resour. 12, 23-30.

Diaz, M., Capilla, E., and Planas, J. V. (2007). Physiological regulation of glucose transporter (GLUT4) protein content in brown trout (Salmo trutta) skeletal muscle. J. Exp. Biol. 210, 2346-2351.

Ewton, D. Z., Falen, S. L., and Florini, J. R. (1987). The type II insulinlike growth factor (IGF) receptor has low affinity for IGF-I analogs: pleiotypic actions of IGFs on myoblasts are apparently mediated by the type I receptor. Endocrinology 120, 115-123.

Ewton, D. Z., Roof, S. L., Magri, K. A., McWade, F. J., and Florini, J. R. (1994). Igf-II Is more active than IgfI in stimulating L6al myogenesisgreater mitogenic actions of Igf-I delay differentiation. J. Cell. Physiol. 161, 277-284.

FAO. (2009). The State of World Fisheries and Aquaculture 200iome: Food and Agriculture Organization of the United Nations (FAO).

Fauconneau, B., and Paboeuf, G. (1998). Histoimmunology analysis of myosin heavy chain expression in skeletal muscle of rainbow trout. Prod. Anim. 11, 154-156.

Fauconneau, B., and Paboeuf, G. (2000). Effect of fasting and refeeding on in vitro muscle cell proliferation in rainbow trout (Oncorhynchus mykiss). Cell Tissue Res. 301, 459-463.

Florini, J. R., Ewton, D. Z., and Coolocan, S. A. (1996). Growth hormone and the insulin-like growth factor system in myogenesis. Endocr. Rev. 17, 481-517.

Gallardo, M. A., Castejon, C., Navarro, I., Blasco, J., Gutiérrez, J., and Sánchez, J. (2001). L-leucine and
L-alanine uptake by trout (Salmo trutta) cardiomyocytes: the effect of IGF-I and insulin. Fish Physiol. Biochem. 25, 239-248.

Gómez-Requeni, P., Mingarro, M. Calduch-Giner, J. A., Médale, F., Martin, S. A. M., Houlihan, D. F., Kaushik, S., and Perez-Sanchez, J. (2004). Protein growth performance, amino acid utilisation and somatotropic axis responsiveness to fish meal replacement by plant protein sources in gilthead sea bream (Sparus aurata). Aquaculture 232, 493-510.

Gómez-Requeni, P., Mingarro, M., Kirchner, S., Calduch-Giner, J. A., Medale, F., Corraze, G., Panserat, S., Martin, S. A. M., Houlihan, D. F., Kaushik, S. J., and Perez-Sanchez, J. (2003). Effects of dietary amino acid profile on growth performance, key metabolic enzymes and somatotropic axis responsiveness of gilthead sea bream (Sparus aurata). Aquaculture 220, 749-767.

Inui, Y., and Ishioka, H. (1983). Effects of insulin and glucagon on amino acid transport into the liver and opercular muscle of the eel in vitro. Gen. Comp. Endocrinol. 51, 213-218.

Johnston, I. A., Bower, N. I., and Macqueen, D. J. (2011). Growth and the regulation of myotomal muscle mass in teleost fish. J. Exp. Biol. 214, 1617-1628.

Kaliman, P., Viñals, F., Testar, X., Palacín, M., and Zorozano, A. (1996). Phosphatidylinositol 3-kinase inhibitors block differentiation of skeletal muscle cells. J. Biol. Chem. 271, 19146-19151.

Kiess, W., Greenstein, L. A., White, R. M., Lee, L., Rechler, M. M., and Nissley, N. P. (1987). Type II insulinlike growth factor receptor is present in rat serum. Proc. Natl. Acad. Sci. U.S.A. 84, 7720-7724.

Kim, J. H., Lee, J. O., Lee, S. K., Moon, J. W., You, G. Y., Kim, S. J., Park, S.-H., Park, J. M., Lim, S. Y., Suh, P.-G., Uhm, K.-O., Song, M. S., and Kim, H. S. (2011). The glutamate agonist homocysteine sulfinic acid stimulates glucose uptake through the calcium-dependent AMPK-p38 MAPK-protein kinase $\mathrm{C} \zeta$ pathway in skeletal muscle cells. J. Biol. Chem. 286, 7567-7576.

Kohn, A. D., Summers, S. A., Birnbaum, M. J., and Roth, R. A. (1996). Expression of a constitutively active Akt Ser/Thr kinase in 3T3-L1 adipocytes stimulates glucose uptake and glucose transporter 4 translocation. J. Biol. Chem. 271, 31372-31378.

Lawrence, J. C., Piper, R. C., Robinson, L. J., and James, D. E. (1992). GLUT4 facilitates insulin stimulation and cAMP-mediated inhibition of glucose transport. Proc. Natl. Acad. Sci. U.S.A. 89, 3493-3497.

Legate, N. J., Bonen, A., and Moon, T. W. (2001). Glucose tolerance and peripheral glucose utilization in rainbow trout (Oncorhynchus mykiss), American eel (Anguilla rostrata), and black bullhead catfish (Ameiurus melas). Gen. Comp. Endocrinol. 122, 48-59.

Marti-Palanca, H., Martinez-Barbera, J. P., Pendon, C., Valdivia, M. M. Perez-Sanchez, J., and Kaushik, S. (1996). Growth hormone as a function of age and dietary protein: energy ratio in a marine teleost, the gilthead sea bream (Sparus aurata). Growth Regul. 4, 253-259.

Méndez, E., Planas, J. V., Castillo, J., Navarro, I., and Gutiérrez, J. (2001). Identification of a type II insulin-like growth factor receptor in fish embryos. Endocrinology 142, 1090-1097.

Mingarro, M., Vega-Rubin de Celis, S., Astola, A., Pendon, C., Valdivia, M. M., and Perez-Sanchez, J. (2002). Endocrine mediators of seasonal growth in gilthead sea bream (Sparus aurata): the growth hormone and somatolactin paradigm. Gen. Comp. Endocrinol. 128, 102-111.

Montserrat, N., Sanchez-Gurmaches, J., Garcia de la Serrana, D., Navarro, M. I., and Gutierrez, J. (2007a). IGF-I binding and receptor signal transduction in primary cell culture of muscle cells of gilthead sea bream: changes throughout in vitro development. Cell Tissue Res. 330, 503-513.

Montserrat, N., Gomez-Requeni, P., Bellini, G., Capilla, E., PérezSánchez, J., Navarro, I., and Gutiérrez, J. (2007b). Distinct role of insulin and IGF-I and its receptors in white skeletal muscle during the compensatory growth of gilthead sea bream (Sparus aurata). Aquaculture 267, 188-198.

Navarro, I., Castillo, J., Albalat, A., Codina, M., Rojas, P., Díaz, M., Pérez-Sánchez, J., Planas, J. V., and Gutiérrez, J. (2003). "Endocrine control of metabolism in myocytes and adipocytes in teleost fish," in 4th Congress Australian International Education Conference, Córdoba.

Negatu, Z., and Meier, A. (1995). In vitro incorporation of [14C]glycine into muscle protein of Gulf Killifish (Fundulus grandis) in response to insulin-like growth factor-I. Gen. Comp. Endocrinol. 98, 193-201.

Pérez-Sánchez, J., and Le Bail, P.-Y. (1999). Growth hormone axis as 
marker of nutritional status and growth performance in fish. Aquaculture 177, 117-128.

Pérez-Sánchez, J., Marti-Palanca, H., and Kaushik, S. J. (1995). Ration size and protein intake affect circulating growth hormone concentration, hepatic growth hormone binding and plasma insulin-like growth factor-I immunoreactivity in a marine teleost, the gilthead sea bream (Sparus aurata). J. Nutr. 125, 546-552.

Pessin, J., and Saltiel, A. R. J. (2000). Signaling pathways in insulin action: molecular targets of insulin resistance. J. Clin. Invest. 106, 165-169.

Rauch, C., and Loughna, P. (2005). C2C12 skeletal muscle cells exposure to phosphatidylcholine triggers IGF-1 like-responses. Cell. Physiol. Biochem. 15, 211-224.

Reinecke, M., Björsson, B. T., Dickhoff, W. W., McCormick, S. D., Navarro, I., Power, D. M., and Gutiérrez, J. (2005). Growth hormone and insulin-like growth factors in fish: where we are and where to go. Gen. Comp. Endocrinol. 142, 20-24.

Rescan, P. Y., Gauvry, L., Paboeuf, G., and Fauconneau, B. (1994). Identification of a muscle factor related to $\mathrm{MyoD}$ in a fish species. Biochim. Biophys. Acta 1218, 202-204.

Rescan, P. Y., Paboeuf, G., and Fauconneau, B. (1995). "Myosatellite cells of Oncorhynchus mykiss: culture and myogenesis on laminin substrates," in Biology of Protozoa Invertebrates and Fishes: In vitro Experimental Models and Applications, Vol. 18. (Plouzané: IFREMER Editions), 63-68.

Rojas, P., Díaz, M., Navarro, I., Pérezsánchez, J., Planas, J. V., and Gutiérrez, J. (2004). "Presence of GLUT4 homolog in skeletal muscle of gilthead seabream (Sparus aurata)," in 5th International Symposium on Fish Endocrinology, Castellón.

Saltiel, A. R., and Kahn, C. R. (2001). Insulin signalling and the regulation of glucose and lipid metabolism. Nature 414, 799-806.

Soengas, J. L., and Moon, T. W. (1995). Uptake and metabolism of glucose, alanine and lactate by red blood cells of the American Eel Anguilla rostrata. J. Exp. Biol. 198, 877-888.

Soengas, J. L., and Moon, T. W. (1998). Transport and metabolism of glucose in isolated enterocytes of the black bullhead ictalurus melas: effects of diet and hormones. J. Exp. Biol. 201, 3263-3273.

Tengholm, A., and Meyer, T. (2002). A PI3-kinase signaling code for insulin-triggered insertion of glucose transporters into the plasma membrane. Curr. Biol. 12, 1871-1876.

Tse, C., and Young, J. (1990). Glucose transport in fish erythrocytes: variable cytochalasin-B-sensitive hexose transport activity in the common eel (Anguilla japonica) and transport deficiency in the paddyfield eel (Monopterus albus) and rainbow trout (Salmo gairdneri). J. Exp. Biol. 148, 367-383.

Vega-Rubín de Celis, S., Rojas, P., Gomez-Requeni, P., Albalat, A., Gutierrez, J., Medale, F., Kaushik, S. J., Navarro, I., and Perez-Sanchez, J. (2004). Nutritional assessment of somatolactin function in gilthead sea bream (Sparus aurata): concurrent changes in somatotropic axis and pancreatic hormones. Comp. Biochem. Physiol. A Mol. Integr. Physiol. 138, 533-542.

Wilson, C. M., Mitsumoto, Y., Maher, F., and Klip, A. (1995). Regulation of cell surface GLUT1, GLUT3, and GLUT4 by insulin and IGFI in L6 myotubes. FEBS Lett. 368 , 19-22.

Young, J., Yao, S., Tse, C., Davies, A., and Baldwin, S. (1994). Functional and molecular characteristics of a primitive vertebrate glucose transporter: studies of glucose transport by erythrocytes from the pacific hagfish (Eptatretus stouti). J. Exp. Biol. 186, 23-41.

Zierath, J. R., Bang, P., Galuska, D., Hall, K., and Wallberg-Henriksson, H. (1992). Insulin-like growth factor II stimulates glucose transport in human skeletal muscle. FEBS Lett. 307, 379-382.

Zorzano, A., Fandos, C., and Palacin, M. (2000). Role of plasma membrane transporters in muscle metabolism. Biochem. J. 349, 667-688.

Conflict of Interest Statement: The authors declare that the research was conducted in the absence of any commercial or financial relationships that could be construed as a potential conflict of interest.

Received: 28 July 2011; accepted: 30 March 2012; published online: 26 April 2012.

Citation: Montserrat N, Capilla E, Navarro I and Gutiérrez J (2012) Metabolic effects of insulin and IGFs on gilthead sea bream (Sparus aurata) muscle cells. Front. Endocrin. 3:55. doi: 10.3389/fendo.2012.00055

This article was submitted to Frontiers in Experimental Endocrinology, a specialty of Frontiers in Endocrinology.

Copyright $\odot 2012$ Montserrat, Capilla, Navarro and Gutiérrez. This is an openaccess article distributed under the terms of the Creative Commons Attribution Non Commercial License, which permits non-commercial use, distribution, and reproduction in other forums, provided the original authors and source are credited. 